\title{
Role of Agronomic Practices in Buffering Impacts of Climatic Change on Coffee (Coffea arabica L.) Productivity
}

\author{
Daba Etana* Dawit Merga \\ Ethiopian Institute of Agricultural Research, Jimma Agricultural research center
}

\begin{abstract}
Synopsis
The role of coffee (Coffee arabica L.) in supporting producers had been closely to ancient practices, currently and the hope of next generation. It is the only crop which more than 25 million people in the world depend on, and the second most important commodity next to oil. However, in recent decades, coffee production has been influenced by severity of climatic changes. Agronomic practices have great function in sustain coffee production due to their attribution in buffering climatic change. Thus, this review conducted with the intension of agronomic practices task in buffering of climatic change impacts in coffee production and productivity. Because of climate change, the optimum production zone for coffee is projected to decrease up to $40 \%$ and at the end of this century, temperature will rise by $4-6^{\circ} \mathrm{C}$. This severity and hazardless will tremendous in developing countries which extremely vulnerable to the risk. Furthermore, deforestation due to over population and absence of awareness in agroforestry are another problem increases the risk of climate change. Familiarity of contributions of agronomic practices in mitigating climate change is less recognizing and practiced informally than improve and scientific way. However, shading has capacity to reduce air temperature by $4^{\circ} \mathrm{C}$, banana intercropping with coffee contributed as sources of income in off season for coffee yield. Finally, agronomic practices such as shading, mulching, irrigation, intercropping, pruning and soil conservation practices are the best option for sustaining coffee production and for buffering the direct and indirect impacts of climatic changes.
\end{abstract}

Keywords: Agronomic practices, buffering, Climate change, Coffee arabica

DOI: $10.7176 / J N S R / 12-21-01$

Publication date: November $30^{\text {th }} 2021$

\section{Introduction}

More than 141 species of coffee are found and originated in different belt of tropical African countries. Three species of coffee are used as beverage, namely Coffea arabica, C. canephora, and C. liberica. Coffee arabica is originated in south western parts of Ethiopia and the most cultivating among the three coffee species due to its quality, rich aroma, and low caffeine content (Santos et al., 2016). Coffee canephora is the next contributing coffee production which is used as sources of disease resistance and high yielder but less priority on the market due to high in caffeine content and woody bitter (Reyes, 2010).

Coffee is one of the most important global crops and provides a livelihood of more than 25 million of people whose living in developing countries (DaMatta et al., 2018). Despite its principal contribution in economic development, coffee arabica is more vulnerable to climate change due to adapt a very narrow of daily temperature $\left(18-23^{\circ} \mathrm{C}\right)$, hate cold and frost temperature and highly sensitive to rainfall variability and drought.

Optimum production zones for coffee are projected to decrease up to $40 \%$ due to rise in temperature and rainfall variability (Adhikari et al., 2015). As a result, it is highly under risk and threat to be disappeared in near to 2080 if not any control method. Hence, due to climate changes and hazard, productivity of coffee arabica at the center of origin will be descended (Craparo, 2015).

Climate change is the most threat to reduce agricultural production and resources to the susceptible area. According to Institute of Environmental Health (IEH) (2012) report, the adverse effect of climate change on agriculture is occurred predominantly in developing countries, mainly at sub-Saharan Africa, and to a lesser extent South Asia. The other dangerous expectation is using back ward farming system and unsystematically intensive agriculture such as deforestation and without or less conservation practices are dominantly carrying out.

Our planet is saturated or balanced before wounded by intensive agricultural practices and other anthropological activities. Natural balance is affected by two factors; (1) byproduct of industries and (2) over population. Developed countries released byproduct from industries, while developing countries influenced deforestation and mismanagement of the nature. Hence, climate change and back ward farming system is the most cancer for natural balances. Indeed, about $80 \%$ of Ethiopian peoples are agrarian, and live in rural area, over population and climate change is most endeavors to wound natural balances. More, environmental balance is currently wounding by the users.

In developing countries, the dogma and capacity to act buffering of climate change still an infant stage. However very few of governmental body, nongovernmental organization (NGO) interfered and protected from devastation through awareness creation to the users. Furthermore, the symptoms of climate change and growth and yield reduction of coffee tree is the alarming of needed extra buffering techniques to sustain its cultivation (Venera et al., 2014). 
Climate smart agriculture (CSA) emphasis on improving risk management, support and develop buffering techniques, information flows and local and international institutions (Abraham and Ebisa, 2017). However, the intensity of adaptation required beyond a narrow current magnification lens to include agronomic buffering techniques (DaMatta et al., 2018). Those techniques are; suitable farming systems, local adaptation planning, building responsive governance systems, enhancing leadership skills, and building asset diversity.

Quite a few information from the studies and modeling scenario revealed that, the idea of climate change is accepted and real. Most of scientists and government bodies now believe that the warming trend is largely growth up without any descending (Baker and Haggar, 2007). Several assessments on the climate change reported that, temperature will be increased by $1.4-5.5^{\circ} \mathrm{C}$ and rainfall will decline by $2 \%$ to $30 \%$ at the end of 21 st century (Baker and Haggar, 2007; IPCC, 2014; Cheserek and Gichimu, 2012).

To alleviate and reduce climatic change effects in coffee production critical question should be answered. The role of agronomic practices is the most applicable and easily practiced at all scale of farmers and environmentally acquaintance (Moa et al., 2017). Those important agronomic practices used in buffering in coffee cultivations are; pre planting preparation, appropriate seedling preparation, planting system, mulching, shading and its management, pruning, intercropping, optimum fertilizer application, integrated managements, soil and water conservation and irrigations. The way of overcoming and sustaining its production is known as buffering practices, due to unable to totally distracting climate change problems.

Developing the methods used to resist or reduce to make coffee production withstand climate change impact is known as buffering. This also plays great role in the mitigation and adaptation practices. On this point of view, the role of agronomic practices in the buffering of climatic change impacts on the production and productivity of coffee is the sanctuary. Based on this, the objective of this review was to review on agronomic practices used in buffering of climatic change impacts on coffee arabica sustainable productivity.

\section{Origin of Coffea arabica}

Coffea arabica L. is primary originated at South-western highlands of Ethiopia and strongly correlated with economy and culture of the country. This truth was justified by observation of responsible scientists and travelers and more recently by several studies using DNA based genetic markers (Tounekti, 2017). Thus, Ethiopia is the central origin of Arabica coffee which is growing under diverse environmental condition (Yigzaw, 2005; Taieb,

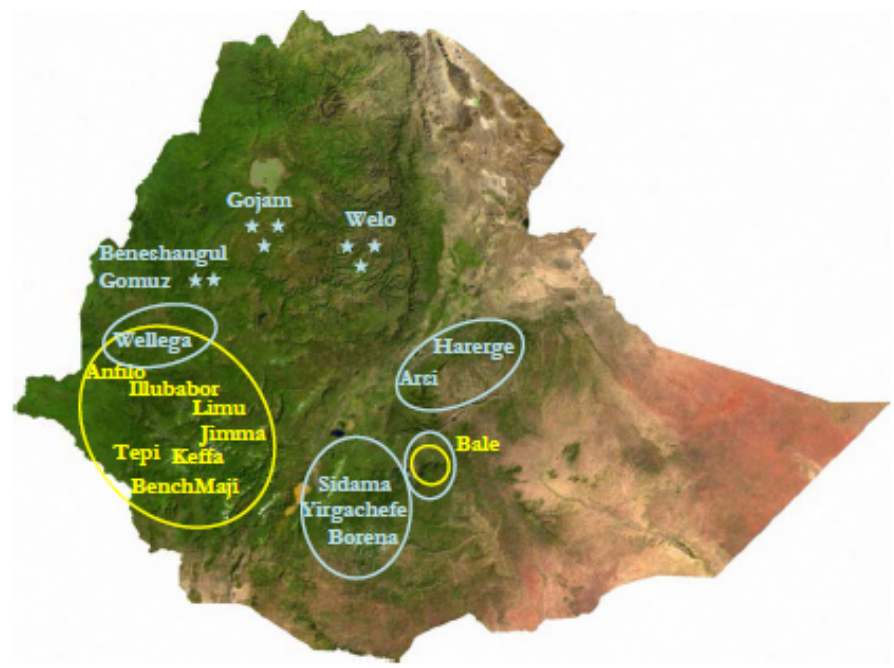
2017).

The current habit of coffee arabica is highly analogues to the situation of area of environmental originated. Based on nature of origin and compatibility, the huge production of coffee arabica in Ethiopia is covered by south and south western parts. Currently, origin and under production areas of coffee production in Ethiopia is listed in Fig 1(Labouisse and Kotecha, 2008).

Figure 1: Main coffee producing areas. natural habitat (yellow circles), managed in forests and gardens (blue circles and stars).( Labouisse and Kotecha, 2008).

Despite, Coffee arabica is served as sources of income and practices as cultural value, production is highly endangered by climate variability and change which significantly reduced its production (Moat et al., 2017).

\subsection{Agro-ecology of Coffee arabica}

Arabica coffee is adapted at the tropical forests of Ethiopia, Kenya, and Sudan, at altitudes of 1500- $2800 \mathrm{~m}$, between the latitudes of $4^{\circ} \mathrm{N}$ and $9^{\circ} \mathrm{N}$ (Camargo, 2010). In Ethiopia, Southwest, Southeast and Eastern parts of the country (Oromia and Southern Nations, Nationalities and Peoples' Regions) are main coffee growing. Coffee arabica is also cultivated in minor production at the northern Ethiopia (Amhara and Benishangul Gumuz) regions under different types of production systems ( Moat et al., 2017). Therefore, it grows under diverse agro-ecologies and wider ranges of weather elements like; altitudes, temperature, rainfall, humidity and soil types (Mesfin and Bayetta, 1987).

Coffee arabica is highly influenced air temperature and depend on seasonal fluctuation. It adapted narrow ranges of annual air temperature with a mean between $18-22^{\circ} \mathrm{C}$ (Moat et al., 2017). It needs well distributed 
rainfall varying from 1600 to $2000 \mathrm{~mm}$, with a dry season lasting three to four months coinciding with the coolest period (Camargo, 2010). South Western parts of Ethiopia at where coffee is originated and conducive for its production typically receive $1500-2100 \mathrm{~mm}$ rainfall per year (Lubuosse and Kotecha, 2008). The optimum temperature, rainfall and soil $\mathrm{pH}$ of coffee arabica is different from the other coffee species (Table 1). Table 1: Optimal and absolute growing conditions for Arabica and Robusta coffee

\begin{tabular}{|c|c|c|c|c|c|c|c|c|}
\hline \multirow[t]{3}{*}{ Growing conditions } & \multicolumn{4}{|c|}{ Arabica } & \multicolumn{4}{|c|}{ Robusta } \\
\hline & \multicolumn{2}{|c|}{ Optimum } & \multicolumn{2}{|c|}{ Absolute } & \multicolumn{2}{|c|}{ Optimum } & \multicolumn{2}{|c|}{ Absolute } \\
\hline & Min & Max & Min & Max & Min & Max & Min & $\operatorname{Max}$ \\
\hline Temperature $\left({ }^{\circ} \mathrm{C}\right)$ & 14.0 & 28.0 & 10.0 & 34.0 & 20.0 & 30.0 & 12.0 & 36.0 \\
\hline $\mathrm{RF}(\mathrm{mm})$ & 1,400 & 2400 & 750 & 4200 & 1700 & 3000 & 900 & 4000 \\
\hline Soil pH & 5.50 & 7.00 & 4.30 & 8.40 & 5.00 & 6.30 & 4.00 & 8.00 \\
\hline
\end{tabular}

Source: EcoCrop/FAO, 2011, http://fao.org/ecocrop

Above optimum temperature may cause several problems on the physiological growth and yield quality. Higher air temperature makes over leaf production, overbearing and dieback to the primary and secondary branches, abnormal fruit development and accelerated ripening, and leading to loss of quality. Continuous exposure to daily temperatures as high as $30^{\circ} \mathrm{C}$ could result in not only depressed growth but also in abnormalities such as yellowing of leaves (Damatta and Ramalho, 2006). A relatively high air temperature during blossoming, especially if associated with a prolonged dry season, may cause abortion of flowers (DaMatta et al., 2018).

On the other hand, Coffee production in regions with a mean annual air temperature below $18{ }^{\circ} \mathrm{C}$, growth is largely depressed. Air temperature under $18{ }^{\circ} \mathrm{C}$ may causes occurrence of frosts, and strongly limit the economic success of the crop (Camargo, 2010). The yield reduction happens due to frost and cold to the coffee arabica is may be reach up to $100 \%$ yield loss if it occurs at the time of flowering for long period of one to two months consecutively.

Similarly, the humidity is highly important in regulating physiological activities of coffee. In the coffee growing areas of Ethiopia, humidity is mainly linked to rainfall and temperature. In the dry season, (October to January/February) the monthly average relative humidity ( $\mathrm{RH} \%$ ) of a typical coffee growing area of the South West zone is less than 55\%, and the wet season (June to September) above 55\%. There is a considerable difference in humidity between day (low RH \%) and night (high RH \%). The amount of sun (sunshine hours) is linked to seasonality, cloud cover and less sunshine in the wet season(s), while less cloud and more sun in the dry season.

\subsection{Diversities and Production system of Coffea arabica}

Arabica coffee (Coffea arabica) is a plant restricted in forest and adapted to the south western highlands of Ethiopia and a small area in neighboring South Sudan (Davis et al., 2012). The information from background study of coffee revealed that, the early users was collected fruits of coffee from the wild forest without any restriction with semi-domestication possibly coming soon afterwards (Moat et al., 2017).

In Ethiopia 5,196 coffee accessions conserved by IBC and including collection carried out at international and national level 4,780 accessions were conserved by JARC from 1966 to 2006 means over 40 years (Labouisse et al., 2008); from 2007 to 2019 around 2197 accessions, totally, 6977 coffee accessions had been collected and conserved by JARC at Melko and different implementing centers and sub-centers (Table). However, out of total coffee accessions collected by JARC $15.33 \%$ were extinct by different environmental factors. Thus, In Ethiopia over 12,173 coffee accessions had collected and 11,103 conserved up to date.

Despite the existence of enormous genetic diversity and importance of the crop in the national economy of the country, its production potential hardly exceeds 0 . the average national coffee productivity 0.619 -ton ha-1 clean coffee (SCA,2018).

In Ethiopia different unknown types of coffee production systems were existed. Simbir fachase, buna bajji, intercropping with spices, chat and other horticultural fruits were taken as example. However, there are four types of known production system found in the country (Woldetsadik and Kebede, 2000; Labouisse and Kotecha, 2008).

In Ethiopia, more than 525,000 hectares $\left(5,250 \mathrm{~km}^{2}\right)$ lands under coffee cultivation (Teferra, 2015). Although the actual area conducive for coffee is probably in excess of $20,000 \mathrm{~km}^{2}$. Forest coffee is account only $5 \%$ in current Ethiopian coffee production. Semi-forest coffee cover more covered about 35\% shared national production systems. Both systems predominate in south-western Ethiopia (Labouisse and Kotecha, 2008).

The third is in garden cultivation system, which covered larger parts of coffee national products, $40-50 \%$. Plantation is the fourth earlier coffee production system and accounted 10 to $20 \%$. Forest and semi forest coffee is differentiated by the degree of managements, forest to little management under forest is forest coffee, whereas high degree is semi forest (Gezahegn and Chemeda, 2015).

Around $30 \%$ of the country's foreign exchange income comes from this single commodity crop (Alazar, 2017). Ethiopia exported around 384,000 metric tons of coffee at a value in excess of 110 million USD, making it Africa's largest Coffee producer and the world's fifth largest Coffee arabica . exporter (ICO, 2019). It also provides significant employment opportunities in rural areas and sustains the livelihood of around 15 million in the country 
which account $16 \%$ of population (Davis et al., 2012). Despite of all paramount roles, this sector become hindered by different major constraints.

\subsection{Challenges of Current and Future coffee production}

The major challenges facing the coffee sector are the threats of coffee genetic erosion and potential to cease its production. These constraint factors are such as disease and pest prevalence insects, replacement of coffee by other crops, coffee market price fluctuation, climate change and variability are major challenges especially for forest natural and organic coffee (Moat et al., 2017; Birhanu, 2018).

From all constraints, the impacts of weather variability and climate change is the most threat for future coffee production due to genetic erosion and become opportunistic factors for abiotic and biotic factors. The inputs of climate change such as; over population, land use conflict, deforestation, over expansion of coffee plantation, and urbanization decreasing Ethiopian coffee forest from time to time (Birhanu, 2018). In addition, pests and diseases such as Trips, Berry borer, Anastasia bug and threat blight become important constraints (GACSA, 2015).

The indigenous coffee arabica was reduced by $65 \%$ in the number of pre-existing bio climatically suitable localities, and at worst an almost 100\% reduction at 2080 (David et al., 2012). Concerning climate change, data from weather stations of Ethiopia showed that the mean annual temperature has increased by $1.3{ }^{\circ} \mathrm{C}$ between 1960 and 2006, at an average rate of $0.3{ }^{\circ} \mathrm{C}$ per decade in the south western region (Jury and Funk, 2013).

In addition, spring and summer rains have declined by $15-20 \%$ since the mid-1970s and late 2000 s in southern, south-western and south-eastern Ethiopia (McSweeney et al., 2010). The mean annual temperature of Ethiopia is projected to increase by $1.1-3.1^{\circ} \mathrm{C}$ by the $2060 \mathrm{~s}$, and $1.5-5.1{ }^{\circ} \mathrm{C}$ by the $2090 \mathrm{~s}$ (Birhanu, 2018). Due to climate change in $2020 / 2021$ coffee production would decline by $34 \%$, and profits around $\$ 20 /$ acre will be reduced (Mofatto et al., 2016).

\section{Causes of Climate Change}

Climate changes is often revealed and slogan of production and productivity losses. Whether recognized or mysterious, the climate change is become relevant all over the world. Particularly, in tropical and sup tropical, revealed through weather elements variability (Birhanu, 2018). But the definition of climate change is little beat differ from weather variability.

The average total of each weather element or rigorously, as the statistical description in terms of the mean and variability of relevant quantities over a period ranging from months to thousands or millions of years" and the classical period for average of these variables in 30 years is known as climate (ITC, 2010). Climate change is defined as those changes occurred from observed for more than 30 years due to anthropogenic and natural drivers of climate (CCAFS, 2016).

Warming of climate system via human activity is clear due to increases in the concentrations of greenhouse gas (GHG) releases to the atmosphere (Moatt et al, 2017). Currently, the atmosphere and oceans warmed, the amounts of snow and ice have diminished, the sea level has risen, and the concentrations of GHG such as carbon dioxide $\left(\mathrm{CO}_{2}\right)$ and methane $\left(\mathrm{CH}_{4}\right)$ have been increased (IPCC, 2013; DaMatta et al., 2018). Now a day, about 6.5 billion tons of $\mathrm{CO}_{2}$ are emitted globally in each year; mostly through burning fossil fuels and changes in land-use mean of 1-2 billion tons of $\mathrm{CO}_{2}$ (Addugna, 2011; Abrahm and Ebisa, 2017). Greenhouse gas is partitioned major portion of happening climate change which released from Industrial zone.

\subsection{Impacts of climate change on Arabica coffee production scenario}

Climate change is expected to decrease the productivity of any crop due to fluctuations existed in growth length, increasing water stress, incidence of diseases, pests and weeds outbreaks (Niang et al., 2014). Coffee species have been highly sensitive to climate change, such as rising temperatures and changing rainfall patterns (Damatta et al., 2018). As prediction from sophisticated models showed global warming honestly affects global coffee production in the $21^{\text {st }}$ century (Baker and Haggar, 2010). Considerable studied were declared about the impacts of climate change. Several impacts of climate change in the coffee production were reported (Baker and Haggar, 2007).

\subsubsection{Deteriorating of physiological growth and fruit quality}

Coffee growth and development highly affected by climate change. Higher air temperature may cause, water stress, less optimum micro climate elements, disturb up and down movements of mineral and nutrients. More, the lifespan of coffee production under rise air temperature will be under question. In addition, climate change due to frost is the other most difficult impacts on the coffee growth and physiology. In 2016, different parts of Ethiopia are affected by frost. Current climate change become opportunistic for the out beak of unknown coffee insect pests; for instance, Fig 2 showed coffee fields affected by insect in Ethiopia which is observed around Jimma, Limmu, Nedgo, Guji and south western (Tamiru 2017, unpublished).

Temperature has potential to influence quality of fruit chemical contents. Increased air temperature will hasten ripening period of Arabica coffee. Thus, the quality contents of the fruit fall as ripening hastened by up normal raised temperature (Baker and Haggar, 2007). If temperature raised by $3^{\circ} \mathrm{C}$ at the end of this century, it 
will be the upper limit for good quality (Baker and Haggar, 2007). In addition, high temperatures during blossoming under prolonged dry season, may often cause abnormal flower development, whereas very high short wave $\left(49^{\circ} \mathrm{C}\right)$ of temperature for 45 and 90 minutes completely inhibit (DaMatta et al., 2018).
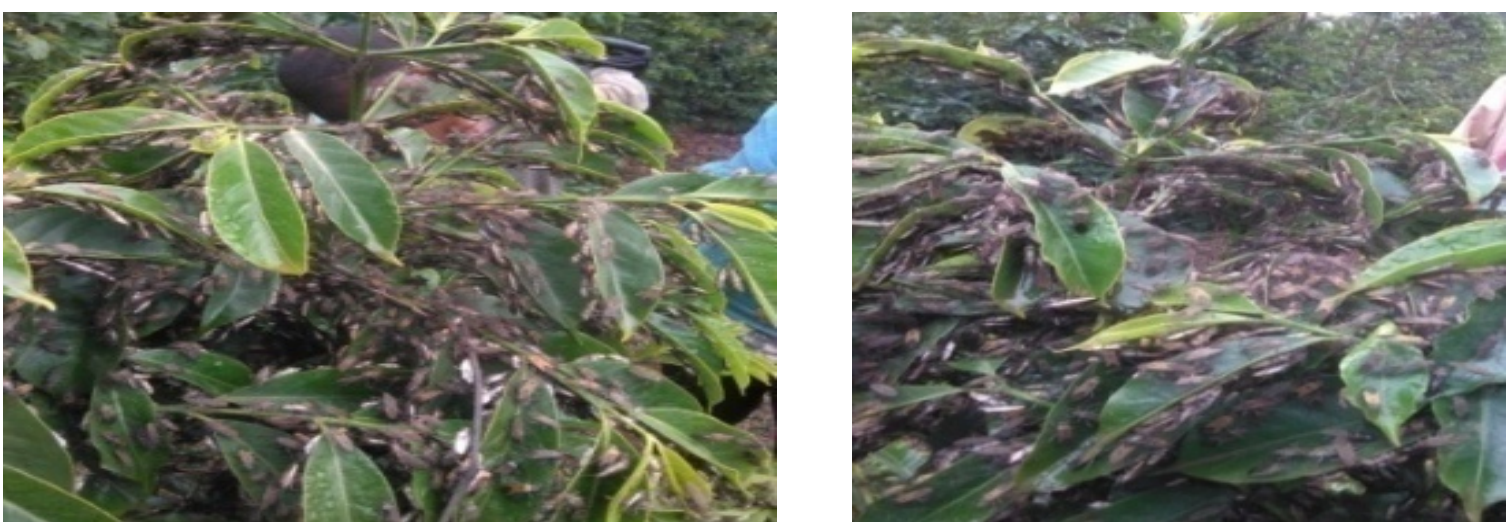

Figure 2: Newly emerging coffee insect pest due to climate change (Tamiru, 2017)

\subsubsection{Coffee yield reduction}

Over normal weather parameters such as temperature, light, wind, rainfall, humidity causes coffee yield reduction. The impacts of rise temperature from climate change frequently observed, specifically at low lands. For instance, low land areas (altitudes less than $1500 \mathrm{~m}$ a.s.l), coffee yields will be adversely affected due to temperature. As reported by Foulnier and Stefano (2004), the yield obtained from Ciudad Colon, Costa Rica from the altitude of $750 \mathrm{~m}$ a.s.l have been severely damaged by high average and high maximum temperatures (Fig 3 ). In similar cases, overbearing which causes dieback of branches, drying the plagiotropic and orthotropic, and some cold and frost effects which may causes $100 \%$ yield losses. More, it is inevitable that the lowest altitude coffee will under the risk.
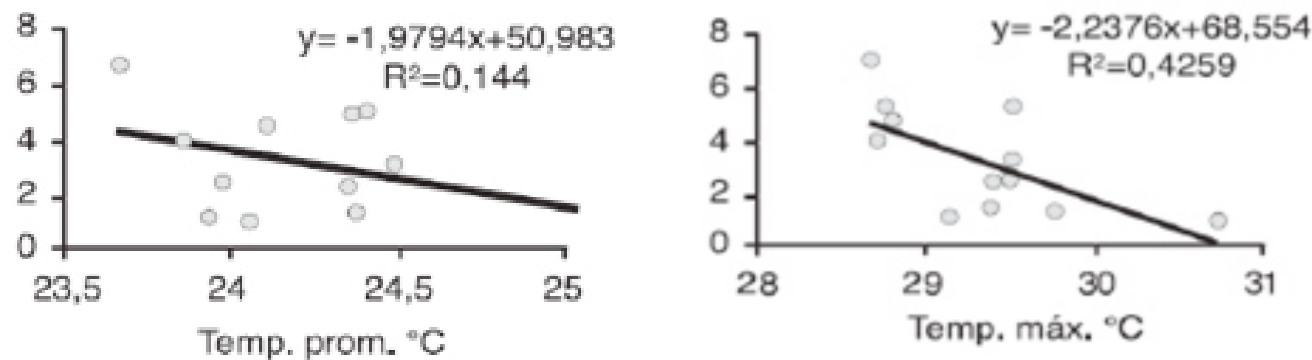

Figure 3 : Yield decline due to maximum temperature (Fourner and Stefano, 2004).

\subsubsection{Relocation from current area}

This point was reported by different scholars, coffee production in Ethiopia may be shifted from the current favorable area to the near and central parts of the country, due to more favor to the coffee arabica productions (Moatt et al., 2017). Similarly, other coffee producers than Ethiopia like Brazil, production could move further north or south, though the patterns of predicted precipitation decline suggest that such opportunities might be rather few (Baker and Haggar, 2007).

\subsubsection{Pest and Diseases}

Temperature increases will favor certain pests and a disease, e.g. the coffee berry borer, which currently has little impacts over 1500 to $1600 \mathrm{~m}$ a.s.l in many countries (Baker and Haggar, 2007). Likewise, coffee rust will increase its altitude range. Some disease and pests that are currently of little importance may achieve greater prominence. Human diseases such as leishmanaisis, malaria, and dengue may become more prevalent in farm workers. The coffee berry borer (Hypothenemus hampei), the most important pest of coffee worldwide, has already benefited from the temperature rise in East Africa: increased damage to coffee crops and expansion in its distribution range has been reported (Jaramillo et al., 2011). This is revealed in Ethiopia and economically important. In 2017 , according to Tamiru, (2017) reported Trips are more revealed when rainfall is rained and interrupted for more than one month (Fig 4) and devastated up to $100 \%$ of coffee production. 

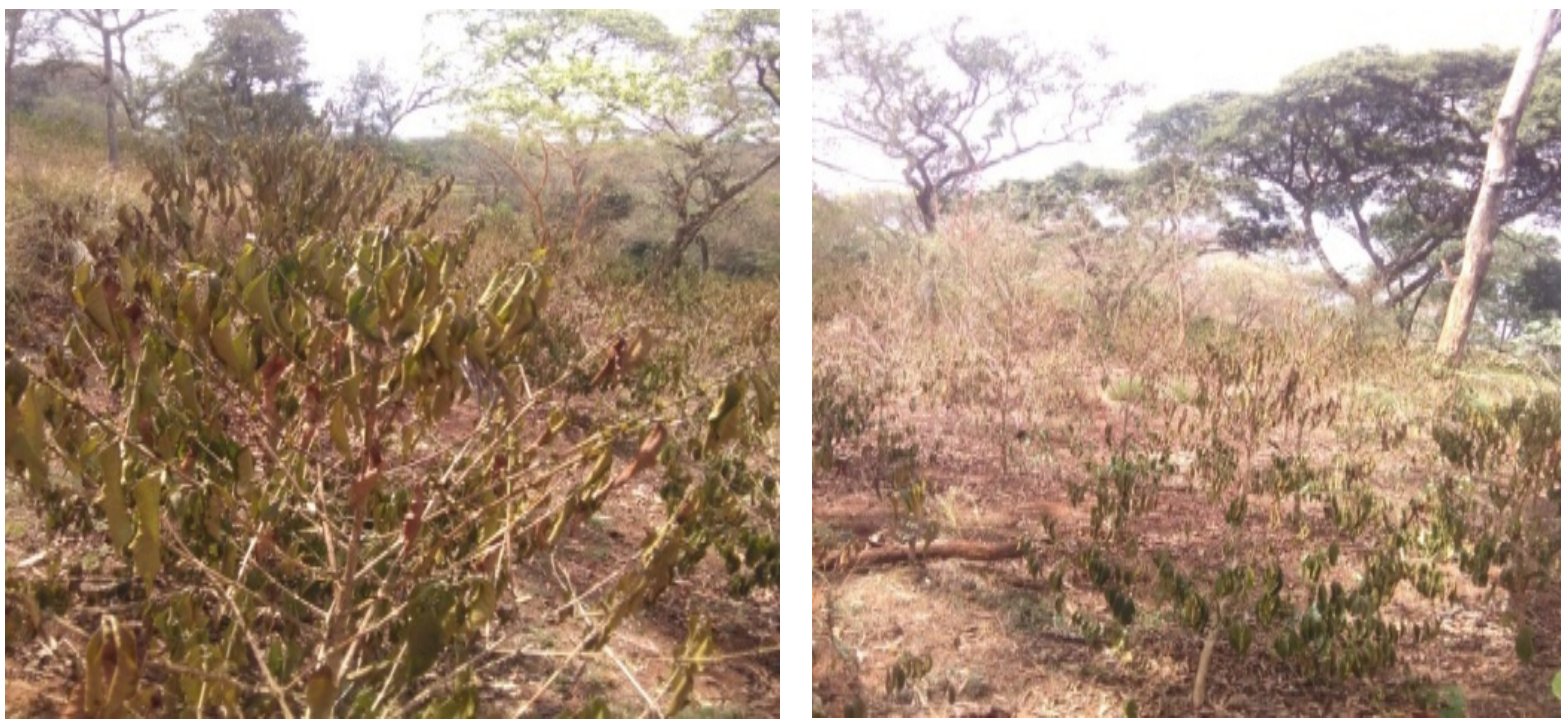

Figure 4: Arabica coffee dried by Trips at Limmu (Tamiru, 2017)

\subsubsection{Soils exposed to hazards and less productivity}

Greater erosion is likely due to increased severity of rainstorms, whereas soils will dry out faster as temperatures rise (Baker and Haggar, 2007). Soil microorganisms used in decomposition should be affected by high temperature and available inorganic matter which need decomposition may be stayed for multiple years.

\subsubsection{Reduction of adapted shade trees species}

Shade trees protects from increased temperatures by making sun heat energy in to latent heat especially in droughts, though competition with coffee for available soil moisture will need careful study (Baker and Haggar, 2007). Due to climate change, susceptible species and need fertile soil species are extinct and replaced by hardy, deep feeder and highly compete for nutrients and water type trees.

\subsubsection{Genetic Erosion by replacements}

There will be increased interest in varieties that are more resistant to drought and since there is little genetic variation available within the coffee arabica genome and its close relatives, as compared other coffee species. It will cause temptation to loss several accession which may have other noble characters than resist climate change. Developed countries like Brazil, Central America Scientists are already doing this (Baker and Haggar, 2007).

\subsubsection{Instability of society and political disruption}

Low land areas in coffee producing that currently grow will be completely unsuitable, uneconomic for any food crop, causing rising food prices, and make political unrest. The human competition to survive at highland will be high and increased pressure to grow more coffee in addition to food security responsible crops (Baker and Haggar, 2007).

\subsubsection{Global output}

The setting of adequate air temperature limits for coffee is decisive for the distribution and economic exploitation of the crop (Camargo, 2009). Fewer parts of the globe very suitable for growing coffee, especially quality coffee. This will lead to a concentration in production, that has already been happening over the last 30 years (Baffes et al., 2005). Consequently, the optimal climate conditions for Arabica coffee cultivation in most of the current production regions are likely to change. Due to, higher temperatures, increasing pest attacks lead to loss of quality of the coffee beans or even to the destruction of yield and plants which may disturb global output.

\section{Methods used to buffer impacts of Climate change on Coffee production}

Buffering of climate change impacts are practiced in formal and informal ways. The idea of climate change and hazard buffering was described by different authors (Moatt et al., 2107; DaMatta et al., 2018). It was reported various mechanisms which are possibly applicable to mitigate climate change in coffee production and quality assurance.

However, developing adaptation and mitigation technologies for coffee production is huge dilemmas for the scientists and frequently asked by the producers. Fundamental scientific research using different coffee crop management, genetic breeding, new molecular tools and agronomic technologies on coffee copping systems particularly in marginal lands, is a challenge to be handled (Camargo, 2010; Jeremy and Kathleen, 2012). Appropriate agronomic adaptation measures could ensure resilience and mitigation for coffee production (Moatt et al., 2017). 


\subsection{Agronomic practices in buffering of climate change}

The two most prominent strategies were pertinent by IPCC (2014) in climate change scenarios. Those are; 1) to demonstrate the effect of agronomical mitigations (production system and plant management) and 2) agronomical adaptation (breeding programs) strategies (Camargo, 2010; Abraham and Ebisa, 2017; Damatta et al., 2018).

Agronomic techniques can be used alone or in a complementary way to mitigate extreme meteorological events and to face the challenge of climatic variability or global warming and promote coffee production (Camargo, 2010; Abraham and Ebisa, 2017). It intervenes air and soil temperature, and moisture to provide a buffer against inadequate growing conditions and extreme weather events (Moat et al., 2017). The most obvious and applicable agronomic practices and mutual with coffee productions discussed below.

\subsubsection{Pre-condition strategy}

Pre-condition strategy is the way to develop varieties with good canopy, deep growth root structure, leaf inclination and area, dormancy science and adapted ability. Small coffee plants with denser canopies are prone to lower transpiration rates, whereas plants with larger and deeper root systems could explore and increased soil volumes, intercept water tables than shallow root varieties (DaMatta, and Ramalho, 2006; Damatta et al., 2007). However, the implementation of these strategies to develop selected cultivars requires several years; hence, ready to use strategies should be implemented, namely, those that effectively mitigate the negative environmental impacts on currently cropped cultivars (Jeremy and Kathleen, 2012). This can be even more important when dealing with tree crops that have a productive lifespan of several years or decades, as it is the case with coffee.

\subsubsection{Hardening of coffee seedlings}

Coffee seedlings are often grown under shade before being transplanted to the field. Thus, at seedling phase, coffee plants are extremely sensitive to sharp exposure to high irradiance and to drought. Production of seedlings directly in full sunlight is now considered a viable option due to the superior performance (e.g., less photooxidative damage) of these seedlings compared to their counterparts grown in the shade (Moraes et al., 2012). In addition, hardening of seedlings to their water supply before transplanting them to the field can improve their survivorship and early growth (Novaes et al., 2010).

Indeed, coffee plants can develop a differential acclimation in concepts of drought existence memory. In this case, when subjected to repeated drought events, potentiating their defense mechanisms and allowing them to be kept in an "alert state" to successfully cope with further drought events (Menezes-Silva, et al., 2017). Together, acclimation of seedlings to both irradiance and water supply would ultimately result in a relatively low mortality rate and improved growth after transplanting, which would therefore decrease the costs of establishing a coffee plantation (Damatta et al., 2018).

\subsubsection{Mulching}

Covering the soil with different materials (e.g. compost, manure) not only helps to preserve soil moisture and decrease soil temperature (reducing evapotranspiration), but it can also increase soil fertility, suppress weeds, and improve rainfall penetration into the ground. Mulching has been used to good effect in Kenya, Tanzania and other countries in East Africa (Moat et al., 2017).

\subsubsection{Shading}

From buffering methods in climate change, shading is the hope of sustainable coffee production through improve coffee growing conditions by reducing air and soil temperatures and increasing humidity and soil moisture. Around $4^{\circ} \mathrm{C}$ of day time temperature differences existed between shaded and unshaded plots (DaMatta et al., (2018). The ameliorative effects of shading have been ascribed to the lower radiation input at the level of the coffee canopy along with reduced wind speeds and temperature fluctuations by as much as $4-5{ }^{\circ} \mathrm{C}$, higher relative humidity, and changes in the aerodynamic roughness of cropped areas (Oliosi et al, 2016; Rodríguez-López at el., 2012).

Effective shade management can also counter the negative effects of heavy rain (e.g. run-off prevention, and coffee flower protection from heavy raindrops) and drying winds ((Moat et al., 2017). Shading is recommended for adopting to avoid large reductions in night temperature at high elevation in order to reduce frost damage (Carr, 2001; Caramori et al., 2003). In marginal areas, and due to predicted future temperature increases coupled with other global climate changes, shading is likely to become an increasingly important management option and a key strategy to mitigate the negative impacts of climate change (Moat et al., 2017).

Adequate shade management can also improve the water status of both the soil and coffee plants after prolonged drought (Oliosi et al, 2016). These ameliorative effects may reduce the extent of oxidative stress and the associated photo-oxidative damage, ultimately improving coffee growth and production, especially in hot, dry regions (Dmatta et al., 2012). In addition, the reduced air temperature in shaded plantations can decrease maintenance respiration by as much as $40 \%$, as found in coffee plants (Charbonnier et al., 2017).

Other beneficial features of shaded plantations include reduced damage to berries caused by sun scorch, greater conservation of natural resources, increased biodiversity, and smaller fluctuations in biennial production (Damatta et al., 2018). Shade trees can also guarantee supplementary income from fruit and/or timber to coffee farmers. In addition, the use of shelter trees can be a sustainable and financially viable coping strategy for smallholders who have little access to technological improvements for mitigating the harmful consequences of 
global climate change (Millard et al., 2011).

In each of these cases, the level of shade should be neither so high that productivity is markedly reduced nor too low to effectively protect coffee plants from adverse environmental conditions (Millard et al., 2011). It is often assumed that a coffee tree shade system is beneficial ecologically as well as economically (Rahn et al., 2013) though a significant decrease in coffee yield if not well managed. Optimal shade levels are likely to be below $50 \%$, especially for coffee that receives fertilization or supplemental irrigation (Vergara et al., 2014).

Coffee plants grown in the shade suffer less from environmental stresses resulted from climate change and have higher biochemical and physiological potential for carbon fixation and produce larger and heavier beans with better taste quality than coffee plants grown in full sun light (Addugna, 2011; Moatt et al., 2017). Jassogne et al. (2013) reported that, 54 farmers who were interviewed individually, $93 \%$ had shade in their coffee garden in Uganda. The intensity level of shade was estimated that, at altitude above $1400 \mathrm{~m}$ majorities of farmers use up to $40 \%$ shade level, but at less than $1400 \mathrm{~m}$, more farmer uses above $40 \%$ of shade intensity (Fig 5). In fact, logically lowland areas needed intensive shade than mid to highland area.

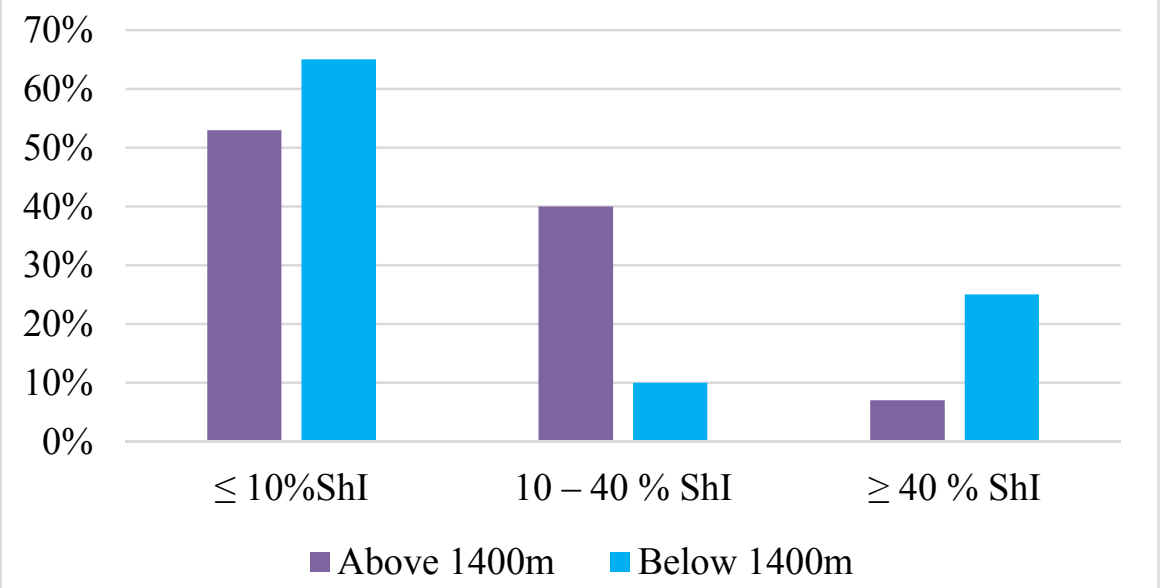

Fig 5. Shade intensity at different altitudes (Jassogne et al., 2013). ShI = shade intensity.

\subsubsection{Coffee Agro-forestry}

Beyond improving micro climate in bioclimatic condition, there was highly intimation between coffee agro forestry at all systems of coffee production. The relation between different shade tree, other economic importance in coffee productions were illustrated in Fig 6. As compared to coffee alone plots without shade, diversified systems offer the lower risks with food and income generated, while monocrop coffee systems can offer better yields; if well managed with well applying fertilizer and give yield for short period of life span (Jassogne et al., 2013).

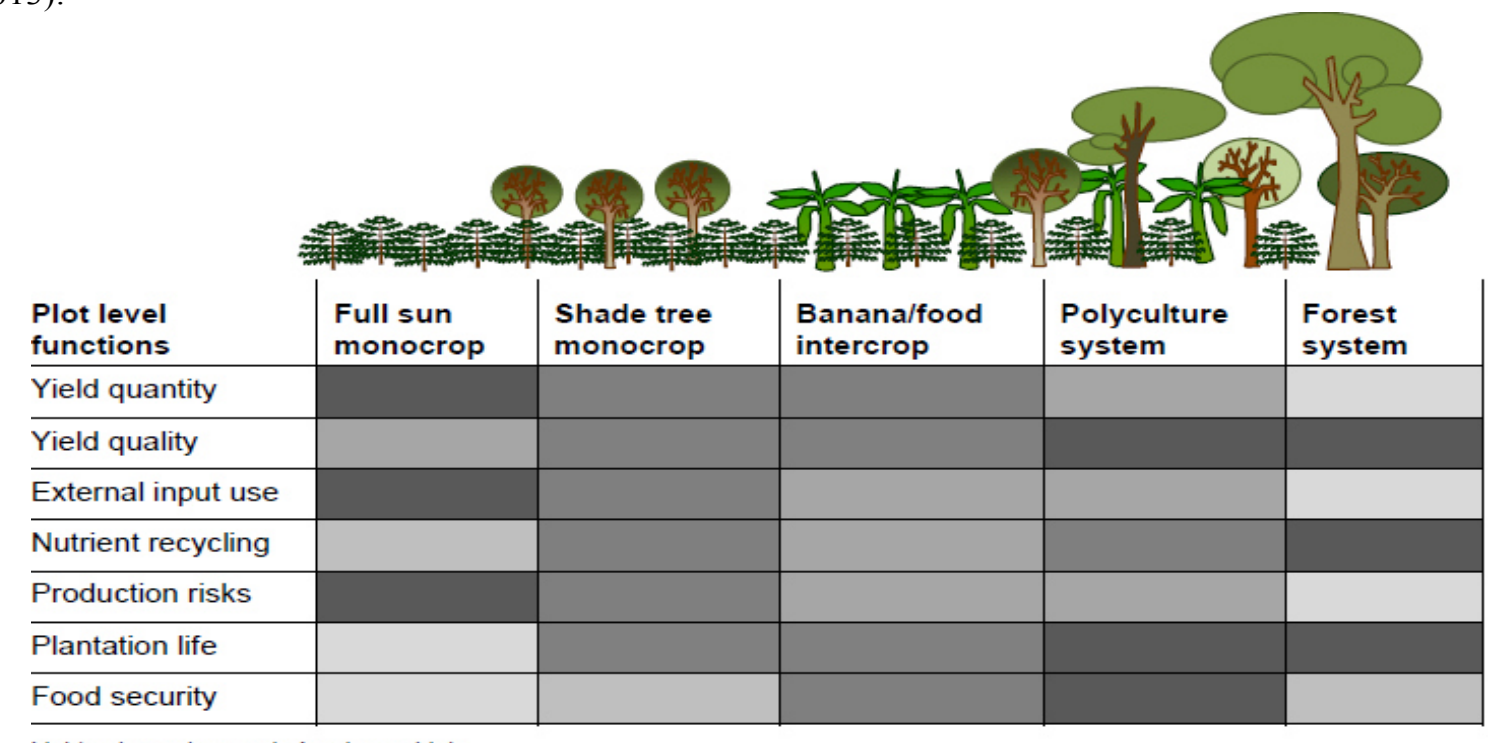

Light colour $=$ low $\rightarrow$ dark colour $=$ high

Figure 6: Illustration of trade-offs at farm/plot level in coffee systems (Photo taken from (Jassogne et al., 2013)

\subsubsection{Irrigation}

The use of supplements of water to improve and/or maintain soil water availability for coffee plants is an ancient and highly effective means of buffering temperature impacts (Moat et al., 2017). Supporting through irrigation 
system, coffee can be successfully produced as supplementary under less optimum rainfall and full irrigated of the fields. DaMatta et al., (2018) reported that, Coffee plants show the habit of high-water use efficiency (WUE) and low transpiration rates. Positive correlations of long-term WUE with the relative growth rate as well as with bean yields have been found in C. arabica, suggesting that selection for high WUE might increase growth and productivity (Dias et al., 2007). Therefore, mitigating its production supporting with irrigation take as option.

\subsubsection{Planting at high densities}

This agronomic practice is new idea on coffee which compacting size and especially suitable for planting in smaller spacing between row and plants. It is the latest trend in Brazilian coffee growth (Fazuoli et al., 2007b). It allows maintaining it more grown leaves, providing a suitable microclimate, with lower air temperatures inside the plant, in relation to the external environment (Fazuoli et al., 2007a). Therefore, this practice presents smaller productions per plant, but increasing the production per area (Camargo, 2010).

\subsubsection{Covering soil}

Covering under the coffee plantation is the methods of vegetated the soil with covering forage, legumes or other plant species (Camargo, 2010). This vegetated covering the face of the soil should be important for maintaining and reducing splash erosions during the rainy season (Thomaziello et al., 2000). Besides the good soil conservation practice, the maintenance vegetated soil reduces the soil and air temperatures and allows a better plant root system distribution because the superficial roots are affected by the high air temperatures (Moat et al., 2017).

This handling also increases the organic matter tenor and the soil water retention capacity making possible a more tolerant cultivation to the adverse climatic conditions (Camargo, 2010). Cover crops planting in similar manner also improve soil moisture availability, nutrient enhancement and serve as shade tree (Magrach, 2015). For instance, desmodium is used as multipurpose such as, cover crop in the coffee plantation, weed control, and feed for animals.

\subsubsection{Biological Terracing}

Terracing has numerous benefits, including drastic improvements in soil quality (e.g. an increase in depth, moisture, and fertility), and reductions in water run-off and soil erosion. Moat et al. (2017) reported that, biological terracing provided multi benefits in mitigating climate change. Planting hedges, control erosion, increase water table are its advantages of biological terracing. In addition, it is used to mitigate wind and water deficiency are important mechanism to withstand negative climate change impacts (Mufato et al., 2016).

\subsubsection{Pruning}

This can improve coffee harvests by maximizing cropping potential and re-invigorating old, unproductive trees. Improvements in yield can offset losses encountered during previous harvests. Pruning may also help to improve water-use efficiency in coffee plants (Moat et al., 2017). Pruning and handling to remove unnecessary branches, flowers and berries that computes to appropriate use of water/nutrients (Mtenga et al., 2011).

\subsubsection{Preventing from biotic stress}

Biotic stresses, such as important coffee disease, leaf rust (Hemileia vastatrix), and important epidemics (e.g., coffee leaf miner; Trips; coffee thread blight; blotch leaf miner) affects the crop, resulting in severe defoliation (Jassogne et al., 2018). Proper control of pathogens and insect attacks should be mandatory. Furthermore, coupled with adequate fertilization and irrigation (and related agronomic practices, such as the incorporation of organic matter into the soil and mulching terraces in high-slope areas), should markedly decrease the negative impacts of these biotic constraints on the agronomic performance of coffee plantations (Jaramillo et al., 2011).

\subsubsection{Coffee Banana Intercropping}

Intercropping coffee with bananas potentially contributes to climate change adaptation through increasing the appropriate microclimate for coffee growing. The dual advantages of bananas include provision of shade, controlling stomata closure during extreme water deficit and reducing transpiration, which allows banana to remain highly hydrated under drought stress. Banana plant competes less with the coffee plant for water than some other shade trees (Haggar., 2012). Marginal rate of returns of adding banana to mono-cropped coffee was 911\% and 200\% in Arabica and Robusta growing regions, respectively (Vanhasten et al., 2011). Fig 7 showed that, average banana harvested of $12.5{\mathrm{t} . \mathrm{ha}^{-1} \text {.year }}^{-1}$, farmers can offset cash flow constraints value about USD 10,000 in the years that coffee is not yet productive.

\subsubsection{Mulching}

Different grass species and crop residues potentially provide nutrients, soil moisture and reduce evaporation (Zinabu, 2017). Mulching consists of covering the topsoil with organic residues to protect the soil from erosion caused by heavy rainfall, to retain moisture and to decrease surface soil temperature. This is particularly beneficial for agro forestry-based coffee farm in the study area during dry periods due to high biomass obtained from the practices (Zinabu, 2017). 


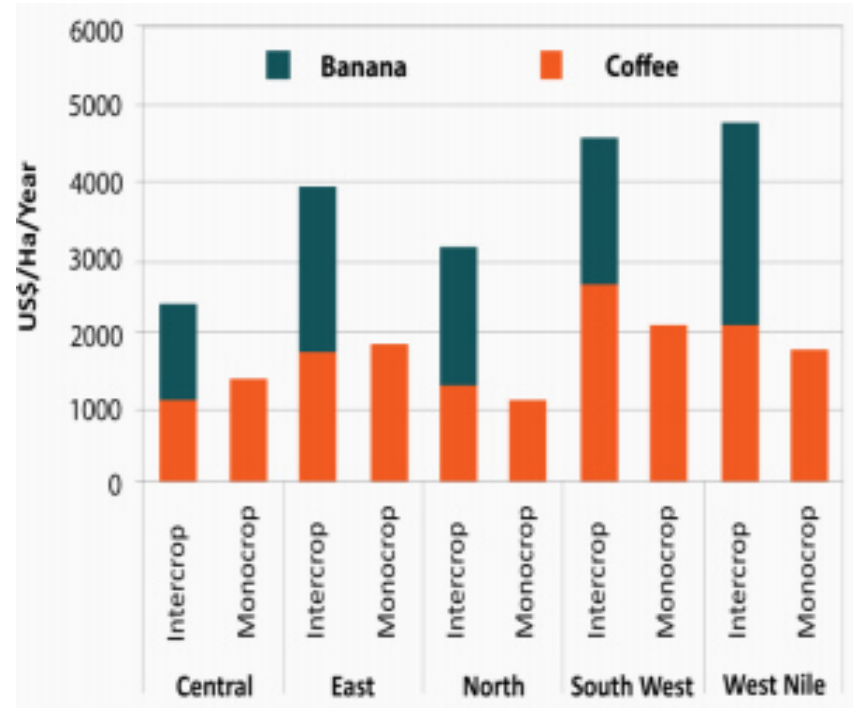

Figure 7: CBI revenues as compared with monocropping (van Asten et al., 2012).

\subsubsection{Rain harvesting}

Rain harvesting and use during dry period in Ethiopia is less practiced. Rain fall harvesting is one of important mechanism to cope with water deficiency (drought season) there by to apply as irrigation. Conserve all the rainy water by forking, digging terraces and mulching which also prevents soil erosion before coffee establishment and inputs to mitigate climate change, specially at to mitigate dry spell.

\section{Summery and Conclusion}

It is an estate of climate that can be identified by changes in the mean and/or the variability of its properties and that persists for an extended period, at least for consecutive 30 years. Climate change is caused by natural and anthropological activities. More hasten by biological competition for surviving. Clearly known that, the relationship between climate change and agricultural production is negative. Specifically, climate variability susceptible crop such coffee arabica is under risk.

So far, the current status of coffee by area of production is less than yield potential. The result of erratic rainfall, flooding, soil erosion, drought, temperature rising, prevalence of disease and quality reduction are more frequently happen and increasing time to time. This indicates that it needs very active managements for the coffee genetic resource origin and production sustainability.

Appropriate adaptation and mitigation strategies allow producer to withstand the climate change challenges. The activities of pre planting selection, appropriate seedling, mulching, terracing, shading, cover crop planting, coffee-banana intercropping, irrigation, and rain water harvest are used to buffering and mitigating climate change impacts.

Fundamental scientific research using different coffee crop management, genetic breeding and new molecular tools and focusing on this subject is highly recommended. Furthermore, impacts of agronomic technologies in coffee cropping systems particularly in marginal lands, is a challenge to be handled within the near future.

Finally, to improve the next decades agricultural productivity, especially the coffee crop, it will be taking attention to integration of breeding, molecular research and agronomic techniques used to adaptation and mitigation of climate change. Furthermore, certainly of buffering techniques will continue to be developed by the technical and scientific world of coffee crop community.

\section{Future directions}

It needs integration of farmers and experts to develop short- and long-term solution of climate change impacts in the coffee production.

A sustainability strategy for Ethiopian coffee production lacking relocation of coffee farms / areas is likely to be ineffective, especially if countrywide production levels are to be maintained or increased.

A concerted effort should be made to identify and establish new coffee areas at higher altitudes.

Resources should be allocated to helping farmers diversify away from coffee in places where climate change has made coffee farming economically unviable.

For many farms, there needs to be greater investment in locally appropriate, cost-effective adaptation measures to improve resilience such as banana intercropping.

Further research is required in order to ascertain the precise outcomes and benefits of on-farm interventions of agronomic practices used to buffering climate change impacts. 
Forest preservation, and re-establishment will play a significant role in adaptation and should be an integral part of future planning

Prevention of forest loss is a key issue, especially in the South West and South East coffee zones where recent deforestation rates are high and could have a more significant impact than climate change at least in the short to medium term.

Attention should also be paid to new and emerging technologies.

A coffee governing body should be ensuring advocacy and effective governance for coffee sustainability and resilience.

\section{References}

Abraham Alemu, and Ebisa Dufera. (2017). Climate Smart Coffee (coffea arabica) Production. American Journal of Data Mining and Knowledge Discovery. 2 (2), pp. 62-68.

Addugna Debala, (2011). Effects of shade on growth, production and quality of coffee (Coffea arabica) in Ethiopia. Journal of Horticulture and Floriculture. 3 (11): pp.336-341.

Adhikari, U., Nejadhashemi, A.P. and Woznicki, S.A., (2015). Climate change and eastern Africa: a review of impact on major crops. Food and Energy Security, 4(2), pp.110-132.

Alazar Shiferaw, (2017). Ethiopia: Coffee export Revenue.

Asten., Wanyama I, Mukasa D, Nansamba R, Kisaakye J, Sserubiri I, Bongers G, Jassogne L (2012). Mapping and evaluating improved intercrop and soil management options for Ugandan coffee farmers, Technical report for Project executed by the International Institute of Tropical Institute.

Baffes J, Lewin B, and Varangis P, (2005). Coffee market setting and policies. In: Global Agricultural Trade and Developing Countries. World Bank, Washington DC. Chapter 16, pp.297- 309.

Baker and Haggar, (2007). Global warming: the impacts on global coffee. SCAA conference handout; Long Beach; Final draft, pp,1-14.

Birhanu Tsegaye. (2018). Coffee Production and Climate Change in Ethiopia. In: Lichtfouse Environmentally Sustainable Agriculture Reviews, 33. pp. 1543-1557.

Camargo, M.B.P.D., 2010. The impact of climatic variability and climate change on arabica coffee crop in Brazil. Bragantia, 69 (1), pp.239-247.

Caramori PH, Grodzki L, Morais H, Juliato H (2003) Efeitoda geada em mudas de café sob diferentes métodos de proteção. In: Book of Abstracts of the III Simpósio de Pesquisas dos Cafés do Brasil, Embrapa Café, Brasilia, pp.66.

Carr, MKV. (2001) The water relations and irrigation requirements of coffee. Experimental Agriculture. 37:1-36.

Central Statistical Agency (CSA) (2018). Agricultural sample survey 2017/ 18. Volume I. Report on area and production of crops (private peasant holdings, Meher season). Statistical bulletin 586, Addis Ababa, Ethiopia.

CCAFS (Climate change agriculture and food security) (2016). Climate change adaptation in agriculture: Practices and Technologies Dinesh D, Vermeulen S(Edition) Messages to the SBSTA 44; Agriculture workshops.

Charbonnier, F.; Roupsard, O.; le Maire, G.; Guillemot, J.; Casanoves, F.; Lacointe, A.; Vaast, P.; Allinne, C.; Audebert, L.; Cambou, A. and Clément-Vidal. (2017), Increased light-use efficiency sustains net primary productivity of shaded coffee plants in agroforestry system. Plant Cell Environment. 40, pp.1592-1608.

Cheserek JJ., and Gichimu BM. (2012). Drought and heat tolerance in coffee: a review International Research Journal of Agricultural Science and Soil. 2(12): pp.498-512.

Craparo, A.C.W., Van Asten, P.J., Läderach, P., Jassogne, L.T. and Grab, S.W., (2015). Coffea arabica yields decline in Tanzania due to climate change: Global implications. Agricultural and Forest Meteorology, 207, pp.1-10.

DaMatta, F.M., Avila, R.T., Cardoso, A.A., Martins, S.C. and Ramalho, J.C., (2018). Physiological and agronomic performance of the coffee crop in the context of climate change and global warming: A review. Journal of Agricultural and Food chemistry, 66 (21), pp.5264-5274.

DaMatta, F. M. (2007). Morphological and physiological responses of two coffee progenies to soil water availability. Journal of Plant Physiology. 164, pp. 1639-1647.

DaMatta, F. M.; and Ramalho, J. D. C. (2006). Impacts of drought and temperature stress on coffee physiology and production: A review. Brazilian Journal of Plant Physiology, 18, pp.55-81.

DaMatta, F. M.; Ronchi, C. P.; Barros, R. S.; and Maestri, M. (2007). Ecophysiology of coffee growth and production. Brazilian Journal of Plant Physiology, 19, pp.485-510.

Davis A.P, Gole T.W., Baena S. and Moat J., (2012). The impact of climate change on indigenous Arabica coffee (Coffea arabica L.): predicting future trends and identifying priorities. PLoS One 7, pp.1-13.

Dias, P. C.; Araújo, W. L.; Moraes, G. A. B. K.; Barros, R. S.; DaMatta, F. M. (2007). Morphological and physiological responses of two coffee progenies to soil water availability. Journal of Plant Physiology 164, 1639-1647. 
EcoCrop/FAO, 2011, http://fao.org/ecocrop.

Fabio M., DaMatta, Rodrigo T. Avila, Amanda A. Cardoso, Samuel C. V. Martins, and José C. Ramalho. (2018). Physiological and Agronomic Performance of the Coffee Crop in the Context of Climate Change and Global Warming: A Review. Journal of Agriculture and Food Chemistry 66, 5264-5274.

Fazuoli, L.C.; Thomaziello, R.A.; Camargo, M.B.P. (2007a). Aquecimento global, mudanças climáticas e a cafeicultura paulista. O Agronomic, 59, 19-20.

Fazuoli, L.C., Silvarolla, M.B., Salva, T.D.J.G., Guerreiro Filho, O., Medina Filho, H.P. and Gonçalves, W.,(2007b). Cultivares de café arábica do IAC, um patrimônio da cafeicultura brasileira.

Fourner LA, and Di Stefano JF, (2004), Variones climaticas etre 1988 y 2001 y sus posibles efectos sobre la fenologa de varias especies lenoss y el manejo un cafetal con sombra en ciudad Colon de cuidad Coloon de Mora: Costarica. Agronomia Costarricense 28 (1): $101-120$.

GACSA (Global Alliance for Climate-Smart Agriculture) (2015). Coffee-Banana Intercropping; Climate Smart Agriculture: Implementation guidance for policymakers and investors.

Gezahegn Berecha Yadessa and Chemeda Abedeta. 2015. Influence of Coffee Production Systems on the Occurrence of Coffee Beans Abnormality: Implication on Coffee Quality. Asian Journal of Plant Sciences 14 (1): 40-44,

Haggar J, Schepp K (2012). Coffee and Climate change impacts and options for adaption in

Brazil, Guatemala, Tanzania and Vietnam, University of Greenwich, Brazil.

International Coffee Organization (ICO). (2019). Historical Data on the Global Coffee Trade; http://www.ico.org/ new- historical.asp, accessed in 2020.

IEH (Institute of Environmental Health) (2012). Analysis of climate change impacts on coffee coca and basic grains value chains in Northern Hondurans.

IPCC (Intergovernmental Panel on Climate Change). Proceedings of the 5th Assessment Report, WGII, and Climate Change (2014): Impacts, Adaptation, and Vulnerability; Cambridge University Press, Cambridge, $U . K$.

ITC (International Trade Centre) (2010). Climate Change and the Coffee Industry, Kasterine A., Scholer M, Hilten HJ (edition), Geneva, Netherland.

Jaramillo J, Muchugu E, Vega FE, Davis A, and Borgemeister C, (2011) Some Like It Hot: The Influence and Implications of Climate Change on Coffee Berry Borer (Hypothenemus hampei) and Coffee Production in East Africa. PLoS ONE 6 (9): e24528.

Jassogne, L., Lderach, P. and Van Asten, P., (2013). The Impact of Climate Change on Coffee in Uganda: Lessons from a case study in the Rwenzori Mountains. Oxfam Policy and Practice: Climate Change and Resilience, 9 (1), .51-66.

Jeremy Haggar and Kathleen Schepp, 2012. Coffee and Climate Change Impacts and options for adaption in Brazil, Guatemala, Tanzania and Vietnam, Natural Resources Institute.4. 1-54.

Jury, M.R. and Funk, C. (2013). Climatic trends over Ethiopia: regional signals and drivers. International Journal of Climatology 33: 1924-1935.

Labouisse., Jean-Pierre and Surendra Kotecha.(2008). Preserving diversity for specialty coffees. A focus on production systems and genetic resources of arabica coffee in Ethiopia, SCAA 20th Annual Conference, Minneapolis.

Labouisse, J.P. and Kotecha, S., 2008. Preserving diversity for specialty coffees. A focus on production systems and genetic resources of arabica coffee in Ethiopia.

Magrach A, and Ghazoul J (2015). Climate and Pest-Driven Geographic Shifts in Global Coffee Production: Implications for Forest Cover, Biodiversity and Carbon Storage. PLoS ONE 10 (7): 1371.

McSweeney, C., New, M. and Lizcano, G. (2010). UNDP Climate Change Country Profiles: Ethiopia. . 27.

Menezes-Silva, P. E.; Sanglard, L. M. V. P.; Ávila, R. T.; Morais, L. E.; Martins, S. C. V.; Nobres, P.; Patreze, C. M.; Ferreira, M. A.; Araújo, W. L.; Fernie, A. R.; and DaMatta, F. M. (2017) Photosynthetic and metabolic acclimation to repeated drought events play key roles in drought tolerance in coffee. Journal of Experimental. Botany., 68, 4309-4322.

Mesfin Amaha and Bayetta Bellachew, (1987). Genotype x environment interaction in Coffee (Coffea arabica L.), 29 June - 3 July 1987. In: Fourth international colloquium on coffee (ASIC) 87, 476 - 482.

Millard, E., (2011). Incorporating agroforestry approaches into commodity value chains. Environmental. Management. 48, 365-377.

Moat, J., Williams, J., Baena, S., Wilkinson, T., Demissew, S., Challa, Z.K., Gole, T.W. and Davis. A.P. (2017). Coffee Farming and Climate Change in Ethiopia: Impacts, Forecasts, Resilience and Opportunities. Summary. The Strategic Climate Institutions Programme (SCIP). Royal Botanic Gardens, Kew (UK). Pp. 37.

Mofatto LS, Carneiro FA, Vieira NG, Duarte KE Vidal RO, Alekcevetch GC, Cotta MG, Verdeil JL, Montes FL, Lartaud M, Leroy T, Bellis FD, Pot D, Rodrigues GC, Carazzolle MF, Pereira GAG, Andrade AC, Marraccini (2016). Identification of candidate genes for drought tolerance in coffee by high-throughput 
sequencing in the shoot apex of different Coffea arabica cultivars, Plant Biology, 16:9.

Moraes, G. A. B. K.; Chaves, A. R. M.; Martins, S. C. V.; Barros, R. S. and DaMatta, F. M.(2012). Why is it better to produce coffee seedlings in full sunlight than in the shade? A morphophysiological approach. Photosynthetic, 48, 199-207.

Mtenga D, Kilambo Dl, Ngomuo R, Mndolwa E, Nkya Eo, and Teri M (2011). Drought Tolerant Coffee Varieties: Development Program in Tanzania.

Niang, I., Ruppel, O.C., Abdrabo, M.A., Essel, A., Lennard, C., Padgham, J. and Urquhart, P., 2014. Africa Climate Change 2014: Impacts, Adaptation, and Vulnerability. Part B: Regional Aspects. Contribution of Working Group II to the Fifth Assessment Report of the Intergovernmental Panel on Climate Change ed VR Barros et al.

Novaes, P.; Souza, J. P.; and Prado, C. H. B. A., (2010). Improving the development of Coffea arabica after changing the pattern of leaf gas exchange by watering cycles. Experience Agriculture., 46, 381-391.

Oliosi, G.; Giles, J. A. D.; Rodrigues, W. P.; Ramalho, J. C. and Partelli, F. L., (2016) Microclimate and development of Coffea canephora cv. Conilon under different shading levels promoted by Australian cedar (Toona ciliata M. Roem. var. Australis). Australian Journal of Crop Science., 10, 528-538.

Rahn E, Läderach P, Baca M, Cressy C, Schroth G, Malin D, Rikxoort H, Shriver J (2013). Climate change adaptation, mitigation and livelihood benefits in coffee production: where are the synergies? Journal of Mitigation Adaptation Strategies, Global Change, 19:1119-1137.

Reyes B., (2010). Coffee Origins. Available from http://www.botecentral.net/coffee-origins.

Rodríguez-López, N. F.; Martins, S. C. V.; Cavatte, P. C.; Silva, P. E. M.; Morais, L. E.; Pereira, L. F.; Reis, J. V.; Ávila, R. T.; Godoy, A. G.; Lavinsky, A. O.; and DaMatta, F. M.(2012). Morphological and physiological acclimations of coffee seedlings to growth over a range of fixed or changing light supplies. Environmental Experimental Botany., 102, 1-10.

Santos Scholz, M.B., Kitzberger, C.S.G., Pagiatto, N.F., Pereira, L.F.P., Davrieux, F., Pot, D., Charmetant, P. and Leroy, T., (2016). Chemical composition in wild Ethiopian Arabica coffee accessions. Euphytica, 209(2), pp.429-438.

Tefera, A. (2015). Ethiopia: Coffee Annual Report. GAIN Report (number ET1514-26/5/2015). USDA Foreign Agricultural Service. Pp 6.

Thomaziello, R.A., Fazuoli, L.C., Pezzopane, J.R.M., Fahl, J.I. and Carelli, M.L.C., (2000). Arabica coffee: crop management. Boletim Tecnico-Instituto Agronomico, (187).

Tounekti, T., Mahdhi, M., Al-Turki, T.A. and Khemira, H., (2017). Genetic diversity analysis of coffee (Coffee arabica L.) Germplasm accessions growing in the Southwestern Saudi Arabia using quantitative traits. Natural Resources, 8(5), pp.321-336.

Van Asten, P., Ochola, D., Wairegi, L., Nibasumba, A., Jassogne, L. and Mukasa, D., (2015). Coffee-banana intercropping: Implementation guidance for policymakers and investors.

Van hasten, P.J.A., Wairegi, L.W.I., Mukasa, D. and Uringi, N.O., (2011). Agronomic and economic benefits of coffee-banana intercropping in Uganda's smallholder farming systems. Agricultural systems, 104 (4), 326334.

Vergara W, Rios AR, Trapido P, and Malarín H (2014).Agriculture and Future Climate in Latin America and the Caribbean: Systemic Impacts and Potential Responses, limitation Change and Sustainability Division.

Wolde, Z., Tefera, A., Yared, S., Gezahagn, T. and Tadesse, T., (2017). A review on coffee farming, production potential and constraints in Gedeo Zone, Southern Ethiopia. Journal of Natural Sciences Research, 7(23), pp.1-9.

Woldetsadik, W. and Kebede, K., 2000. Coffee production systems in Ethiopia.

Yigzaw, D., (2005). Assessment of genetic diversity of Ethiopian arabica coffee genotypes using morphological, biochemical and molecular markers. A PhD Dissertation, University of the free state, South Africa, p.197.

Zelalem Fisseha, Tesfaye, K., Dagne, K., Blair, M.W., Harvey, J., Kyallo, M. and Gepts, P., (2016). Genetic diversity and population structure of common bean (Phaseolus vulgaris L) germplasm of Ethiopia as revealed by microsatellite markers. African Journal of Biotechnology, 15 (52), pp.2824-2847. 